\title{
PRIORITY VECTORS OF MUSIC-PEDAGOGICAL REFLECTON IN THE FEDERAL REPUBLIC OF GERMANY AT THE TURN OF XX - XXI CENTURY
}

\section{Stashevska I. O.}

\section{INTRODUCTION}

The humanistic orientation of the pedagogical science and practice development, the requirements of increasing the spiritual sphere as a strategic resource for the further development of mankind, actualize the systematic scientific and pedagogical search for ways of optimizing music education area as an important factor in the spiritual development of personality from early childhood to old age.

As you know, the definition of music education as one of the main means of forming the spiritual culture of mankind took place in ancient times. Ideas and practical activities of prominent personalities of various national cultures contributed to the formation of ideas about the positive influence of music and music education on personality and society in various aspects (religious, ethical, aesthetic, patriotic, emotional, intellectual, therapeutic, etc.): Confucius, Socrates, Plato, Aristotle, Guido of Arezzo, Ya. A. Komensky, J.-J. Rousseau, H. Skovoroda, J. Pestalozzi, H. G. Nägeli, M. Lysenko, E. Jacques-Dalcroze, R. Steiner, B. Yavorsky, B. Asafyev, Z. Kodaly, C. Orff, D. Kabalevsky and many others.

And today the problem of the functional significance of music and music education attracts the attention of various professional circles of humanity: philosophers, culturologists, educators, musicians-performers, composers, psychologists, sociologists, doctors, state figures, and others.

Prominent role of music education in the transfer of music and cultural traditions, the formation of the music culture of the younger generation, as well as the influence on the spiritual development and humanization of society determines the relevance of studying and implementing the best achievements of world music pedagogy, in particular, Germany, whose musical and educational traditions originate from the earliest times of Charlemagne reign (742-814) by the Frankish Empire, and the music and pedagogical theory in the process of 
historical development has evolved from applied knowledge to an independent scientific branch thanks to the efforts of many generations.

\section{Cultural-anthropological aspects of music-pedagogical reflection in Germany at the end of the $\mathrm{XX}$ - the beginning of the XXI century}

Music pedagogy of modern Germany is an open system, the characteristic feature of which is the pluralism of musical and pedagogical positions, which, on the one hand, promotes the democratization of the music and educational space, and, on the other hand, creates the basis for a permanent scientific and practical discussion on the problems of musical education, upbringing and development.

One of the major tasks of music-pedagogical science in the Federal Republic of Germany at the turn of the second and the third millennium is the study of the cultural and anthropological foundations of music education: the essence of music and its place in the inner and outer world of personality, the phenomenon of music influence and the functional significance of music education in various spheres of human activity and society, the natural music human makings and the factors of their development.

Music in German scientific literature is considered in different perspectives: as an acoustic phenomenon, an acoustic-symbolic system, an aesthetic object - a work of art, language of feelings, historical document, subjective self-expression of the composer, a means of symbolic reflection and knowledge of the inner and outer world of the person, processes and results of social relations, means of communication, education, self-expression and self-realization of the individual, a source of aesthetic pleasure, a cultural phenomenon, which has its own autonomous value, and which every person accepts and understands subjectively based on its own vital (cognitive, emotional, psychomotor, etc.) experience, and so on ${ }^{1}$.

Researchers in the Federal Republic of Germany are investigating a wide range of music influences on human mood and behavior by

1 Günther G. Die gesellschaftliche Relevanz außerschulischer Musikbildung : quantitative Untersuchung $\mathrm{zu}$ Entwicklungschancen und -problemen musizierender Jugentlicher im aktuellen gesellschaftlichen Kontext. Frankfurt am Main: Lang. 2002. S. 14; Kaiser H. J. Zur Bedeutung von Musik und Musikalischer Bildung. Ästhetische Theorie und musikpädagogische Theoriebildung. Mainz. 1998. S. 98-114.; Kraemer R.-D. Musikpädagogik - eine Einführung in das Studium. Augsburg: Wißner. 2004. S. 63. 
empirical and theoretical methods: in public places, for example, in shops, music stimulates the desire to buy, entertains, reduces the risk of theft; in the workplace - increases or decreases productivity; in the process of intellectual activity - helps or disturbs; in the process of watching movies, video clips, and advertising- reinforces the emotional influence of the pictures line; in medicine - affects the autonomic nervous system: changes in the heart rate, rhythm of breath, blood pressure, chemical composition of blood, muscle tension, reduction of pain, sensation of fear, for example, during a visit to a dentist or in preparation for surgery; in psychotherapy - relieves stress, improves mood, normalizes the mental state, etc. ${ }^{2}$

A broad scientific discussion was caused by the problem of the music influence music on the development of cognitive human abilities. Empirically, German scientists also came to the conclusion that, although music has a special emotional and expressive potential, it appears as an intermediary between rational and irrational, conscious and unconscious, thinking and action. In the process of creating, representing, perceiving and playing music, an equal role is played by cognitive, emotional and practical-activity factors, and therefore the music activity is recognized as a means of mental, emotional and physical development of the individual ${ }^{3}$.

As shown by the results of the analysis, the common for the publication of the Federal Republic of Germany is the recognition of multifunctional importance of music in the life of a person and society. At the same time, scientists point to the impossibility of always accurately predicting the impact of music due to the fact that different individuals in different situations react differently to the same musical composition. It is also stated that the music influence can be both positive and negative depending on the music itself, the situation in which it perceives, the degree of intellectual and emotional development of the individual, his past life experience and personality (for example, extravert, introvert, melancholic, choleric, etc.), music experience, ideas and knowledge of a person about the specific music that he/she perceives, and so on ${ }^{4}$.

${ }^{2}$ Behne K.-E. Wirkungen von Musik. Kompendium der Musikpädagogik. Kassel. 1995. S. 339.

3 Günther G. Die gesellschaftliche Relevanz außerschulischer Musikbildung : quantitative Untersuchung $\mathrm{zu}$ Entwicklungschancen und -problemen musizierender Jugentlicher im aktuellen gesellschaftlichen Kontext. Frankfurt am Main: Lang. 2002. S. 21.

${ }^{4}$ Behne K.-E. Wirkungen von Musik. Kompendium der Musikpädagogik. Kassel. 1995. S. 333-348. 
In this regard, a problem of personality music socialization becomes relevant in German society. In the new theories of music socialization, the emphasis is not just on adapting the individual to the music life of society, but on the formation, as a result of taking or, conversely, the rejection of various "offers" of music life, individual style and forms of interaction with music based on knowledge of the positive and negative possibilities of its impact. The concept of "musical self-socialization" emphasizes self-choice role and independent active participation of the individual in the process of involvement in music culture and the formation of the music environment ${ }^{5}$.

Concerts, the music industry, the music interests of parents, relatives, friends, etc., music education activities of mass media, music associations, churches and especially organized music education in kindergartens, comprehensive and music schools, higher educational establishments are determined as important factors in music socialization of a person, in addition to his/her own music activity ${ }^{6}$.

Since the mid-1990s, the concept of "key competencies" or "key qualifications", which define as the ability to solve the problems and gain new experience in the relevant sphere, is becoming popular in the pedagogical circle of the Federal Republic of Germany. And in the late 1990 's, a musical-pedagogical discussion on the orientation of the music-educational process to the formation of key competences that will enable the individual to solve the problems in music art and enrich music experience began ${ }^{7}$.

Music competence perspectives are distributed according to the main types of music activity (music reception, production, reproduction,

${ }^{5}$ Müller R. Selbstsozialisation. Eine Theorie lebenslangen musikalischen Lernens. Empierische Forschungen - Ästhetische Experimente. Wilhelmshaven. 1995. S. 63-75; Pape W. Perspektiven musikalischer Sozialisation. Musikpädagogische Biographieforschung. Fachgeschichte - Zeitgeschichte - Lebensgeschichte. Essen. 1997. S. 140-167; Rösing H. Musikalische Sozialisation. Kompendium der Musikpädagogik. Kassel.1995. S. 349-372.

${ }^{6}$ Pape W. Perspektiven musikalischer Sozialisation. Musikpädagogische Biographieforschung. Fachgeschichte - Zeitgeschichte - Lebensgeschichte. Essen. 1997. S. 158.

${ }^{7}$ Bastian H. G. Musik(erziehung) und ihre Wirkung : eine Langzeitstudie an Berliner Grundschulen. Mainz: Schott. 2000; Bimberg G., Bimberg S. Musikwissenschaft und Musikpädagogik: Perspektiven für das 21. Jahrhundert. Essen: Die Blaue Eule. 1997. S. 25; Gruhn W. Wie entsteht Musikalische Bildung? Von den Chancen und Schwirigkeiten des Musikunterrichts heute. Musik \& Ästhetik. 1999. № 12. S. 52; Kaiser H. J. Kompetent, aber wann? Über die Bestimmung von „musikalischer Kompetenz” in Prozessen ihres Erwerbs. Musikalische Bildung. 2001. № 3. S. 5-10. 
reflection, music transformation into other arts), more than according to the components of musicality (an ear for music, sense of rhythm, music memory, etc.), that is, pragmatic question of preparation for real musical practice becomes relevant: deliberate listening, making music, music discussion, using of media technologies, etc. and, thus, the competent use of music for personal and social purposes. At the same time key elements of music competence include not only specific music knowledge, skills and abilities, but also such personal qualities as creativity, readiness for communication and cooperation, ability to concentrate, initiative, etc. ${ }^{8}$

In connection with awareness of the multifunctional music significance, German researchers seek to empirically bring music education value and the indispensability for the development of various spheres of human life and society. The study of so-called "transfereffect", or "transfer-influence", music education in psychological, social-integrative, moral, therapeutic and other contexts is becoming relevant ${ }^{9}$.

In 1992, a long-term pilot project (1992-1998) on the basis of Berlin's primary schools began; leading to sensational results and received a broad resonance both in Germany and abroad ${ }^{10}$.

The experiment involved pupils from advanced music teaching and regular classes for comparison. The detailed documentation of the study proves that in the pupils of the first group at the fourth year of study observed an increase in the general level of intelligence, success, motivation to study, the ability of creative thinking, concentration, cooperation, communication, integration in the team, objective selfesteem, endurance, readiness for positive interpersonal relationships at school and others. The results of the study allowed his author (H. Bastian) to assert that music education is an ideal means of effective development of the key qualifications required in a modern society: apart from the development of specific music abilities, in the process of

${ }^{8}$ Bastian H. G. Musik(erziehung) und ihre Wirkung : eine Langzeitstudie an Berliner Grundschulen. Mainz: Schott. 2000. S. 305; Gruhn W. Wie entsteht Musikalische Bildung? Von den Chancen und Schwirigkeiten des Musikunterrichts heute. Musik \& Ästhetik. 1999. № 12. S. 52.

${ }^{9}$ Bimberg G., Bimberg S. Musikwissenschaft und Musikpädagogik: Perspektiven für das 21. Jahrhundert. Essen: Die Blaue Eule. 1997.

10 Bastian H. G. Musik(erziehung) und ihre Wirkung : eine Langzeitstudie an Berliner Grundschulen. Mainz: Schott. 2000. 
music education and upbringing, intellectual, creative, aesthetic, social, emotional and psychomotor personal development is carried out ${ }^{11}$.

Convincing evidence of music education possibilities in solving socio-cultural problems became the conclusions of six years' experience scientific study under an experimental project program - "Music Against Violence and Aggression" (since 1994), conducted on the initiative of the famous violinist, conductor and music figure Yehudi Menukhin on the basis of 60 schools from 13 European countries, including Germany. The peculiarity of studying in these schools was in advanced music direction of the curriculum: the students were engaged in singing, dancing, creating music, etc. The results of the study prove a real opportunity to educate a civilized and humane generation by means of musical education ${ }^{12}$.

On 8-9 September, 2003, an International professional congress "Music for children" was organized in Germany, where representatives of various countries reported on the results of research on the capacities of music and music education. The purpose of this event was to draw the attention of all social forces to the music education problems and to emphasize its global significance for the further existence and development of the society ${ }^{13}$.

The main conclusion of the action was to determine the possibilities of the positive music education influence on the mental, social, emotional, aesthetic, creative, mental and physical development of children, qualitative transformation of various aspects of the person's life (meaning of being, communication, personal and social identification, sense of satisfaction, etc.), achievement and preservation of peace and understanding among peoples ${ }^{14}$.

An important conclusion of scientific observation in adult music education was that adult music lessons are not less valuable than in childhood and adolescence to provide a full-fledged life: apart from specifically artistic development, music education contributes to creative potential development, communication skills of an adult person, raises

11 Bastian H. G. Musik(erziehung) und ihre Wirkung : eine Langzeitstudie an Berliner Grundschulen. Mainz: Schott. 2000. S. 624; Bastian H. G. Kinder optimal fördern mit Musik. Mainz: Schott. 2001. S. 101.

${ }^{12}$ Bastian H. G. Kinder optimal fördern mit Musik. Mainz: Schott. 2001. S. 65.

${ }^{13}$ Musik bewegt. Positionspapiere zur Musikalischen Bildung / [hrsg. von Deutscher Musikrat]. Berlin: Renk. 2005. S. 7.

${ }^{14}$ Ibid. S. 8. 
the feeling of life joy, self-esteem, helps to survive crisis situations in life, improves mood, working capacity, develops mental self-regulation skills, initiative, endurance, self-discipline ${ }^{15}$.

The results of empirical studies indicate that choral singing in family, church and other public institutions of amateur musicians creates ideal conditions for mutual understanding between different generations ${ }^{16}$.

Analysis and generalization of German educators and scientists justifications for the necessity of music education for society and its individual members allows us to present the main theses of German music pedagogy in this context in the following perspectives:

- anthropological: the creation and experience of music is a special way of human existence, and music is the most natural means of human self-realization, communication with music contributes to the harmonious development of natural potential and the full formation of personality;

- cultural and pedagogical: by nature, a person is a cultural and creative being, music is an integral part of human existence and as a manifestation of human culture should be accessible to every member of society; mastering the values of music culture is carried out in the process of music education;

- general pedagogical: a person is subject to educational influence, and music is a means of upbringing; musical education positively affects not only the development of musical abilities, but also the intellectual, creative, aesthetic, social, emotional, psychomotor development of the personality, the formation of his/her intelligence;

- esthetic-educational: a determining role in the knowledge of the world is played by feelings, each of which allows you to get specific information about reality and can not be replaced by others, and various musical activities provide no indispensable opportunity for the development of the sensory sphere, the aesthetic knowledge of the world and the formation of aesthetic attitude to it;

- socio-pedagogical: music education is an effective means of music socialization of personality, humanization of person and society,

15 Claussen M. Elementare Musikerziehung in Eltern-Kind-Kursen. Augsburg: Wißner. 2001. S. 88-89.

16 Claussen M. Elementare Musikerziehung in Eltern-Kind-Kursen. Augsburg: Wißner. 2001. S. 38; Gembris H. Grundlagen musikalischen Begabung und Entwicklung. Augsburg: Wißner. 2002. S. 425. 
social competence education, which involves communication skills, readiness for social integration and cooperation;

- therapeutic: music education and upbringing create conditions for music-pedagogical therapy ${ }^{17}$.

Thus, music and music education are recognized in Germany by the important socio-cultural needs of a person and society, a catalyst for personal and social processes. At the same time, leading German music teachers warn against excessive utilitarian instrumentalization of music education, and note that despite the results of recent research on positive transfer-effects of music activity on the non-music spheres of human development and society, the professional goals and tasks of music pedagogy theory and practice must remain the priority ones ${ }^{18}$.

\section{Psychological, neurophysiological and didactic aspects of music-pedagogical reflection in the scientific space of the Federal Republic of Germany}

An important basis for finding and substantiating the priority ways of music education, upbringing and development considered in the German music-pedagogical literature as components of a holistic musiceducational process in their organic unity and interdependence are psychological and pedagogical research, representing knowledge about how in music abilities and human experience change in the process of life - from birth to old age.

According to the empirical studies of German scientists, the music potential is inherent from the birth of virtually all people, with the exception of people with receptive-sensory deviations. Scientific experiments prove that even before birth (approximately from the seventh month of woman pregnancy), the child can already perceive

${ }^{17}$ Bimberg G., Bimberg S. Musikwissenschaft und Musikpädagogik: Perspektiven für das 21. Jahrhundert. Essen: Die Blaue Eule. 1997. S. 29-43; Kraemer R.-D. Musikpädagogik - eine Einführung in das Studium. Augsburg: Wißner. 2004. S. 53; Lexikon der Musikpädagogik [hrsg. von S. Helms, R. Schneider, R. Weber ]. Kassel: Bosse. 2005. S. $167-168$ and etc.

${ }^{18}$ Bimberg G., Bimberg S. Musikwissenschaft und Musikpädagogik: Perspektiven für das 21. Jahrhundert. Essen: Die Blaue Eule. 1997. S. 308; Günther G. Die gesellschaftliche Relevanz außerschulischer Musikbildung : quantitative Untersuchung zu Entwicklungschancen und -problemen musizierender Jugentlicher im aktuellen gesellschaftlichen Kontext. Frankfurt am Main: Lang. 2002. S. 54-63; Gruhn W. Lernziel Musik. Perspektiven einer neuen theoretischen Grundlegung des Musikunterricht. Hildesheim: Olms. 2003. S. 61-62 and etc. 
acoustic, in particular music signals. Babies recognize words and melodies that they have heard for a long time before birth. However, how "music impressions" of the embryo influence further development is still an open question in psychology. Already in the first months of life children show different music abilities, distinguish rhythmic impulses from arrhythmic ones, high and low sounds, distinguish changes in rhythmic pattern, etc. Three-year-old children easily recognize the mood of music, the sound colour of various instruments. Approximately up to the age of six-seven years, the sense of order is stabilized; abilities for singing are greatly enhanced ${ }^{19}$. At the same time because of the significant individual difference of children it is impossible to determine precisely which abilities correspond each age. Changes in receptive, productive and reproductive music abilities, music interests and tastes can be manifested as acquisition (improvement, enhancement, deepening, etc.) or as loss (restriction, limitation, reduction, etc.) ${ }^{20}$.

Individual differences in music development are due to the possibilities of music experience accumulation, which depend primarily on genetic potential and environmental impact, which can stimulate and support the development of this potential, and vice versa - delay it. The earlier the process of music socialization of a person begins, the greater the chances for the development of natural music makings and for that music will be important for his/her throughout whole life.

Particularly favourable for successful music development is the period from birth to the age of nine. The involvement of children in music culture in the first years of life lays the foundation for the music abilities formation in the period of socio-cultural identification of the person (from the age of 10), which determine the types of human music activity in adulthood. In the preschool age, music interests are largely determined by the parents' influence and preschool educational institutions, in school - the media influence and the same age children. Only after graduation music interests and tastes become stable in most young people and they often remain steady for whole life ${ }^{21}$.

${ }^{19}$ Gembris H. Grundlagen musikalischen Begabung und Entwicklung. Augsburg: Wißner. 2002. S. 98-99; Gruhn W. Lernziel Musik. Perspektiven einer neuen theoretischen Grundlegung des Musikunterricht. Hildesheim: Olms. 2003.

${ }^{20}$ Gruhn W. Lernziel Musik. Perspektiven einer neuen theoretischen Grundlegung des Musikunterricht. Hildesheim: Olms. 2003. S. 51.

${ }^{21}$ Gembris H. Grundlagen musikalischen Begabung und Entwicklung. Augsburg: Wißner. 2002. 
German scientists say that in the period from the age of two to five joining the music language can be done like mastering in native language, music classes in this period contribute to the rapid development of a sound perception sense, metro rhythm, dynamics, rhythm deviation. Conversely, if during this period the child musicality is not developed, then it will be much more difficult to fill the existing lacks later: if the possibilities of acquiring music abilities clearly prevail in the childhood and youth development periods, then the number of losses can significantly increase over the years. However, as the results of experiments show, the processes of acquiring and loss of music abilities depend not only on age, but also on the personal character, intensity of classes and types of music activity. In this regard, the musicality that consists of a set of components in each person can be manifested with specific accents: for example, good ear for music and senso-motoric abilities may be accompanied by underdeveloped music memory; the decrease of senso-motoric abilities of an elderly musician, which negatively affects the level of music and technical skills, may be accompanied by the growth of music experience, the level of knowledge and ability to assess music phenomena, etc. ${ }^{22}$

According to empirical research, young music talents have a complex of intellectual, sensory-emotional, auditory and instrumentaltechnical abilities. They reveal such features of character as ambition, activity, good faith, demanding of themselves, self-criticism. One of the key factors in their music achievements is the early start of music development and the daily, multi-hour music classes, the result of which, in turn, depends on the previous life-long and specifically music experience, thinking peculiarities, feelings and actions, the level of motivation, the ability to concentrate and endure, interests, needs, expectations, emotional and physical condition of the person at the moment of educational and upbringing situation, organizational conditions (institutional, time, etc.), conformity of educational strategies (setting up tasks, selecting methods, forms, pace of classes, etc.) ${ }^{23}$.

${ }^{22}$ Gembris H. Grundlagen musikalischen Begabung und Entwicklung. Augsburg: Wißner. 2002; Gruhn W. Lernziel Musik. Perspektiven einer neuen theoretischen Grundlegung des Musikunterricht. Hildesheim: Olms. 2003; Lexikon der Musikpädagogik [hrsg. von S. Helms, R. Schneider, R. Weber ]. Kassel: Bosse. 2005. S. 53-55.

${ }^{23}$ Bastian H. G. Jugend am Instrument. Mainz: Schott. 1991. 
The generalizations of German scholars modern ideas about the factors of music development of a person can be divided into five types - genetic, general-individual, music-individual, self-directed and externally-directed ${ }^{24}$. The genetic type includes the innate general makings and the music potential of a person; the general-individual one - cognitive, creative, psychomotor and social abilities of the individual; the music-individual type - the level of previous music development of the personality: the abilities of acoustic differentiation, perception, emotion and music expression, music memory, internal auditory imagination, etc.; the self-directed one- the emotional and physical condition of the individual at the time of the educational situation, the ability to endure, self-discipline, diligence, curiosity, love of music, motivation to music activity, music needs, interests and tastes, dedication, energy, positive self-esteem, desire for self-realization, etc.; the externally directed type - the music and cultural environment surrounding the personality, family conditions, intensity, quality and early start of music and pedagogical influence, the interaction level between various social institutions (family, kindergarten, school, church, mass media, etc.), the social recognition level of the individual, etc.

Neurophysiological studies became an important contribution to the formation of theoretical foundations of German music pedagogy that presented learning as a process of changing neural connections: depending on the demand of individual nerve cells of the brain, new connections are created between them, and the integrative nature of music activity, in which cognitive, emotional and physical processes are carried out simultaneously, which provides multi-channel sensory and psychomotor stimulation and balanced work of both brain hemispheres, determines the increase of neutral links and brain activity optimization ${ }^{25}$.

${ }^{24}$ Bastian H. G. Jugend am Instrument. Mainz: Schott. 1991; Entwicklung und Sozialisation aus musikpädagogischer Perspektive [hrsg. von Mechthild von Schoenebeck]. Essen: Die Blaue Eule. 1998; Gembris H. Grundlagen musikalischen Begabung und Entwicklung. Augsburg: Wißner. 2002 and etc.

${ }^{25}$ Gruhn W. Der Musikverstand, Neurobiologische Grundlagen des musikalischen Denkens, Hörens und Lernens. Hildesheim: Olms. 1998; Günther G. Die gesellschaftliche Relevanz außerschulischer Musikbildung: quantitative Untersuchung zu Entwicklungschancen und problemen musizierender Jugentlicher im aktuellen gesellschaftlichen Kontext. Frankfurt am Main: Lang. 2002. S. 23-27; Kraemer R.-D. Musikpädagogik - eine Einführung in das Studium. Augsburg: Wißner. 2004. S. 62. 
Compared with musically uneducated individuals, musically educated ones show more effective information processing both in sensory-emotional and intellectual spheres, as well as increased sensomotoric abilities. Especially scientists emphasize that significant positive changes in the brain structure are possible, if a person began regular music lessons at the age of eight to nine ${ }^{26}$.

In the process of W.Gruhn scientific research it was revealed that there is a fundamental difference in the power of activating brain activity in verbally declarative mastering of music knowledge and in acquiring music experience through practical music activity. More balanced and intensive level of brain activity is observed in the second variant that determines the quality of preservation, processing and future use of the necessary information. Thus, the key to the effectiveness of music education is the form of music experience acquiring - through a real music action or through cognitive learning of terminology, rules, abstract music structures, etc. ${ }^{27}$

Taking into account the conclusions of own research, as well as the of the developmental psychology thesis that thinking arises and develops as a result of and on the basis of action, W. Gruhn notes that music education should have procedural, effective character; declarative education (verbal transmission and mastering of music knowledge) must precede the process of forming music representations through active music activity ${ }^{28}$.

Comparing with verbal language and defining music as a form of human activity, a means of social communication and expression of a person's inner state, similar to a verbal language, the scientist insists that music education should be directed towards the formation of the ability to think musically and "speak" (to express the results of own music thinking through verbal and music performances). He notes, however, that only after the child has learned to speak, he/she can learn to read and write, as well as the sequence of music education should be such

${ }^{26}$ Günther G. Die gesellschaftliche Relevanz außerschulischer Musikbildung: quantitative Untersuchung $\mathrm{zu}$ Entwicklungschancen und problemen musizierender Jugentlicher im aktuellen gesellschaftlichen Kontext. Frankfurt am Main: Lang. 2002. S. 27, 230-231; Gruhn W. Der Musikverstand, Neurobiologische Grundlagen des musikalischen Denkens, Hörens und Lernens. Hildesheim: Olms. 1998. S. 242.

${ }^{27}$ Gruhn W. Lernziel Musik. Perspektiven einer neuen theoretischen Grundlegung des Musikunterricht. Hildesheim: Olms. 2003. S. 103-104.

${ }^{28}$ Ibid. S. 97-98. 
that the lesson content is mastered musically - through listening, singing, playing the instrument, and only after this they discuss, use terms, fix graphic signs or notes, that is, they connect them with verbal and symbolic associations ${ }^{29}$.

Consequently, the personal music activity of the individual is recognized in modern German music-pedagogical literature as the determining factor in the formation of music experience.

Compared with the mass music education problems, issues of special vocal and instrumental pedagogy are paid much less attention in the German scientific space of the last decades. Characteristic for the development of this industry was the desire to generalize and systematize the theoretical foundations of instruction in performing arts, covering knowledge of the peculiarities of general and music development and human learning, the psychology of music performance, the ways and the specifics of mastering music-performing experience in different age periods, the methodology of teaching singing and playing music instrument.

The problems of the development of music talent, the formation of internal music and auditory representations, music thinking, the statement of the performing apparatus, the organization of performing movements, breathing, the upbringing of the individual music and performing style, performing art, psycho-training of future performers, performing the interpretation of music works, early instrumental education, group teaching to play instruments, etc. remain relevant for modern music-pedagogical reflection in the Federal Republic of Germany.

The main purpose of vocal and instrumental education in German publications, which reveals the theoretical foundations of teaching the performing arts, is the development of music abilities, the formation of knowledge, skills and abilities, aesthetic orientations and tastes in music performance, the main principles -dedication, consistency, artistic and technical development unity, balance of mental, emotional and psychomotor, productive and reproductive aspects of music education, personal approach, life-long learning, introducing various music styles and genres into the educational repertoire. The vocal and music instrument teacher is required to have a sufficient level of pedagogical

${ }^{29}$ Gruhn W. Lernziel Musik. Perspektiven einer neuen theoretischen Grundlegung des Musikunterricht. Hildesheim: Olms. 2003. S. 96-99, 107-119. 
and performing skills, as well as personal qualities, which include empathy, respect for students, creativity, initiative, friendliness, selfconfidence, willingness to compromise, cooperation, constant professional and personal self-improvement, etc. ${ }^{30}$

Competition problems of the educational forces of society with the media have become especially relevant in the German-speaking musicpedagogical literature of the late XX - early XXI centuries.

The acute problem is determined by the fact that the media propagate a picture of the world that creates a distorted life perception as a continuous satisfaction that can be achieved without much effort. In this regard, young people are often unable to make realistic assessment of the of the surrounding reality requirements, they are not ready for hard work to succeed ${ }^{31}$.

In addition, an increase time spending by children and young people on a TV or computer leads to a decrease in social activity, psychomotor problems; as a result of prolonged physical rest, mental capacity, concentration is weakened. Besides, audiovisual technologies have their own structure and information presentation dynamics: rapid change of pictures, fragmentation, superposition, variety, the ability to choose at any time more interesting information. The habit of such obtaining method becomes a kind of "antiprogram" for patient waiting, internal concentration, analytical thinking and in-depth reading or listening, without which it is impossible to succeed in the educational process. Unnecessary information overload leads to concentration weakening, a decrease in motivation, difficulties in learning, communication skills are violated; German researchers point it out already in preschool children ${ }^{32}$.

The negative aspect of the modern media technologies impact in the music and pedagogical aspect is manifested in the promotion of stereotyped, meaningless music, as well as the fact that the prolonged television influence dampens the ability to music perception. According to the German studies results, with the growth of music visualization,

30 Handbuch der Musikpädagogik. Instrumental- und Vokalpädagogik: in 2 Bänden [hrsg. von Christoph Richter]. Kassel: Bärenreiter. 1993. Bd. 1: Grundlagen; Spielen und Unterrichten. Grundlagen der Instrumentaldidaktik [hrsg. von Ulrich Mahlert]. Mainz: Schott. 1997 and etc.

31 Recum H. Schule in sozialkulturellen Wandel. Die Deutsche Schule. 1992. № 4. S. 398.

${ }^{32}$ Noll G. Musikalische Früherziehung. Erprobung eines Modells. Regensburg: Bosse. 1992. S. 112. 
audio multi-perceptivity is lost. Advertising on television and radio becomes for many children the main means of their music socialization. Getting acquainted with new music achievements is often carried out within the advertising in which the clichés are being promoted. On the one hand, they give high mark to popular classic music, and on the other hand - modern music is associated with the environment pollution, disease, death. In this way, the children "learn to associate classics with money and wealth, modern music with gray, dirt and environmental problems, and the pop music - with good mood and cheerfulness" - a specialist in music psychology and pedagogy Klaus Ernst Bene writes about it with a bitter irony ${ }^{33}$.

German specialists define the ability of a person consciously, creatively use new technical means in the process of building own musical space as one of the important music and educational tasks. Taking into account the advantages and disadvantages of new multimedia technologies, educators are aware that, despite the informatization and computerization tendency of educational space, one cannot overemphasize the role of these technologies in the process of music education (for example, to organize the educational process solely through computer programs or listening to music only with the help of sound reproducing hardware), that is, the technique is an integral, but one of the additional auxiliary means of music education and upbringing $^{34}$.

\section{CONCLUSIONS}

The results of the analysis allow noting that the cultural and anthropological, psychological, neurophysiological and didactic aspects of music education, upbringing and development occupy a priority place in the music-pedagogical discussion in the Federal Republic of Germany at the end of the XX and the beginning of the XXI century. The leading trends in the development of the music pedagogy theory in modern Germany are: humanistic orientation; theory and practice integration;

${ }^{33}$ Behne K.-E. Wirkungen von Musik. Kompendium der Musikpädagogik. Kassel. 1995. S. 342.

34 Auerswald St. Der Computer im handlungsorientierten Musikunterricht: didaktischer Stellenwert und methodische Konzeptionen. Augsburg: Wißner. 2000; Gerhardt B. Internet und Musikunterricht. Bestandsaufnahme und Perspektiven. Augsburg: Wißner. 2004; Multimedia als Gegenstand musikpädagogischer Forschung [hrsg. von Rudolf-Dieter Kraemer]. Essen: Die Blaue Eule, 2000 and etc. 
music pedagogy cooperation with other scientific disciplines; recognition of music and pedagogical positions pluralism as democratization factor of music and educational space; search for ways of combining the art, general pedagogical and socio-cultural music education perspectives; specialists desire to take into account objective (aesthetic, musicological) and subjective (anthropological, psychological, etc.) requirements, human relationships, music and life, and finding a balance between the guiding principles of music education, upbringing and development.

European countries today have many common social, cultural and educational problems. In this aspect, a positive example is an active and comprehensive German scientist's study of the axiological music education potential as a multidimensional phenomenon that appears to be an effective factor in the development not only of an individual, but whole society.

Cooperation problems of various social institutions in music education (family, musical and general education schools, higher education institutions, music and cultural institutions, professional and amateur bands, enterprises, mass media, music education authorities), issues of searching real possibilities and inhibiting factors of the musiceducational process direction at all its links to the formation of both professional (music-immanent) and social, personal, ethical, aesthetic, media and other competences, music preparation problems of adults music lovers, multicultural orientation of music education and so on still need special attention of scientists.

\section{SUMMARY}

The priority vectors of music-pedagogical reflection in the Federal State of Germany at the end of the XX - the beginning of the XXI century are reviewed in the publication. The importance of studying the best achievements of world music pedagogy, in particular Germany, is emphasized. It is revealed that the study of the axiological potential of music education as a multidimensional phenomenon, which is an effective factor in the development of not only an individual, but also the whole society, is particularly relevant in the German scientific space. The views of German educators and scholars on the value of musical education in the following perspectives are generalized: anthropological, 
cultural-pedagogical, general pedagogical, aesthetic-educational, sociopedagogical, and therapeutic.

The scientific representations about features of musical socialization of the personality, formation of musical competence, development of musical abilities and experience of the person in the process of life, formation in personality ability to knowingly and creatively use new technical means in the process of building own music space are considered. It is established that the cultural-anthropological, psychological, neurophysiological and didactic aspects of music education, upbringing and development took precedence in the musicpedagogical discussion in the Federal Republic of Germany during that period. The leading tendencies of the German music pedagogy theory on the verge of the XX - XXI centuries are determined.

\section{REFERENCES}

1. Auerswald St. Der Computer im handlungsorientierten Musikunterricht: didaktischer Stellenwert und methodische Konzeptionen. Augsburg: Wißner. 2000. 229 s.

2. Bastian H. G. Musik(erziehung) und ihre Wirkung : eine Langzeitstudie an Berliner Grundschulen. Mainz: Schott. 2000. 686 s.

3. Bastian H. G. Kinder optimal fördern mit Musik. Mainz: Schott. 2001. S. 101.

4. Bastian H. G. Jugend am Instrument. Mainz: Schott. 1991. $320 \mathrm{s.}$

5. Bimberg G., Bimberg S. Musikwissenschaft und Musikpädagogik: Perspektiven für das 21. Jahrhundert. Essen: Die Blaue Eule. 1997. $318 \mathrm{~s}$.

6. Behne K.-E. Wirkungen von Musik. Kompendium der Musikpädagogik. Kassel. 1995. S. 333-348.

7. Claussen M. Elementare Musikerziehung in Eltern-KindKursen. Augsburg: Wißner. 2001. 202 s.

8. Entwicklung und Sozialisation aus musikpädagogischer Perspektive [hrsg. von Mechthild von Schoenebeck]. Essen: Die Blaue Eule. 1998. $200 \mathrm{~s}$.

9. Gembris H. Grundlagen musikalischen Begabung und Entwicklung. Augsburg: Wißner. 2002. 475 s.

10. Gerhardt B. Internet und Musikunterricht. Bestandsaufnahme und Perspektiven. Augsburg: Wißner. 2004. 226 s. 
11. Gruhn W. Der Musikverstand, Neurobiologische Grundlagen des musikalischen Denkens, Hörens und Lernens. Hildesheim: Olms. 1998. $285 \mathrm{~s}$.

12. Gruhn W. Lernziel Musik. Perspektiven einer neuen theoretischen Grundlegung des Musikunterricht. Hildesheim: Olms. 2003. $285 \mathrm{~s}$.

13. Gruhn W. Wie entsteht Musikalische Bildung? Von den Chancen und Schwirigkeiten des Musikunterrichts heute. Musik \& Ästhetik. 1999. № $12.153 \mathrm{~s}$.

14. Günther G. Die gesellschaftliche Relevanz außerschulischer Musikbildung : quantitative Untersuchung zu Entwicklungschancen und - problemen musizierender Jugentlicher im aktuellen gesellschaftlichen Kontext. Frankfurt am Main: Lang. 2002. 270 s.

15. Handbuch der Musikpädagogik. Instrumental- und Vokalpädagogik: in 2 Bänden [hrsg. von Christoph Richter]. Kassel: Bärenreiter. 1993. Bd. 1: Grundlagen. 565 s.

16. Kaiser H. J. Zur Bedeutung von Musik und Musikalischer Bildung. Ästhetische Theorie und musikpädagogische Theoriebildung. Mainz. 1998. S. 98-114.

17. Kaiser H. J. Kompetent, aber wann? Über die Bestimmung von „musikalischer Kompetenz” in Prozessen ihres Erwerbs. Musikalische Bildung. 2001. № 3. S. 5-10.

18. Kraemer R.-D. Musikpädagogik - eine Einführung in das Studium. Augsburg: Wißner. 2004. 480 s.

19. Lexikon der Musikpädagogik [hrsg. von S. Helms, R. Schneider, R. Weber ]. Kassel: Bosse. 2005. 295 s.

20. Multimedia als Gegenstand musikpädagogischer Forschung [hrsg. von Rudolf-Dieter Kraemer]. Essen: Die Blaue Eule, 2000. 270 s.

21. Musik bewegt. Positionspapiere zur Musikalischen Bildung / [hrsg. von Deutscher Musikrat]. Berlin: Renk. 2005. 44 s.

22. Müller R. Selbstsozialisation. Eine Theorie lebenslangen musikalischen Lernens. Empierische Forschungen - Ästhetische Experimente. Wilhelmshaven. 1995. S. 63-75.

23. Noll G. Musikalische Früherziehung. Erprobung eines Modells. Regensburg: Bosse. 1992. 312 s.

24. Pape W. Perspektiven musikalischer Sozialisation. Musikpädagogische Biographieforschung. Fachgeschichte Zeitgeschichte - Lebensgeschichte. Essen. 1997. S. 140-167. 
25. Recum H. Schule in sozialkulturellen Wandel. Die Deutsche Schule. 1992. № 4. S. 398.

26. Rösing H. Musikalische Sozialisation. Kompendium der Musikpädagogik. Kassel.1995. S. 349-372.

27. Spielen und Unterrichten. Grundlagen der Instrumentaldidaktik [hrsg. von Ulrich Mahlert]. Mainz: Schott. 1997. 351 s.

\section{Information about the author: \\ Stashevska I. 0.}

Doctor of Pedagogical Sciences, Professor,

Honored Art Worker of Ukraine,

Vice-rector for Educational Work,

Kharkiv State Academy of Culture

4, Bursatskyi uzviz str., Kharkiv, 61000, Ukraine 